\title{
The Absorption of Vocational Education Graduates in The Automotive Sector in The Industrial World
}

\author{
Rio Kurniawan ${ }^{1 *}$, Amat Jaedun ${ }^{2}$, Farid Mutohhari, Wahyu Mustafa Kusuma ${ }^{4}$ (D) \\ 1,2,3,4 Technology and Vocational Education, Postgraduate Program, Yogyakarta State University, Yogyakarta, Indonesia \\ e-mail: riokurniawan.2020@student.uny.ac.id
}

\section{A R T I CLE I N F O}

Article history:

Received June 12, 2021

Revised June 13, 2021

Accepted July 18, 2021

Available online August 25, 202

Kata Kunci:

Graduate Absorption, Automotive

Sector, Vocational Education

Keywords:

Motivation, Work Discipline,

Teacher Performance

DOI:

http://dx.doi.org/10.23887/jet.v5 i3.35365

\begin{abstract}
A B S T R A K
Keterserapan lulusan di dunia industri merupakan aspek penting yang mempengaruhi kualitas sekolah menengah kejuruan (SMK). Namun, permasalahan yang terjadi adalah rendahnya keterserapan tersebut. Penelitian ini bertujuan untuk menganalisis tingkat keterserapan lulusan SMK pada program keahlian teknik kendaraan ringan (TKR) dan teknik dan bisnis sepeda motor (TBSM). Penelitian deskriptif menggunakan pendekatan kuantitatif untuk mengukur persentase keterserapan lulusan. Sejumlah 4 bursa kerja khusus SMK dilibatkan dalam penelitian ini. Teknik dan instrumen pengumpulan data menggunakan metode dan lembar observasi dengan melakukan observasi data survey yang ada di bursa kerja khusus. Teknik analisis data menggunakan analisis deskriptif kuantitatif dan analisis inferensial uji $t$ independen sampel. Hasil penelitian menunjukkan bahwa tingkat keterserapan lulusan SMK pada jurusan TKR dan TBSM rendah. Berbagai upaya untuk revitalisasi pendidikan vokasional harus dimatangkan kembali. Program link and match SMK dengan dunia industri perlu semakin intensif untuk menyelaraskan kompetensi yang diajarkan terhadap kebutuhan kompetensi dunia industri, sehingga keterserapan lulusan mampu ditingkatkan.
\end{abstract}

\section{A B S T R A C T}

The absorption of graduates in the industrial world is an important aspect that affects the quality of vocational high schools (SMK). However, the problem that occurs is the low absorption. This study aims to analyze the level of absorption of SMK graduates in light vehicle engineering (TKR) and motorcycle engineering and business (TBSM) programs. Descriptive research uses a quantitative approach to measure the percentage of graduate absorption. A total of 4 vocational high school job fairs were involved in this study. Techniques and instruments of data collection using methods and observation sheets by observing survey data in special job fairs. The data analysis technique used quantitative descriptive analysis and inferential analysis of the sample independent $t$ test. The results showed that the level of absorption of SMK graduates in the TKR and TBSM majors was low. Various efforts to revitalize vocational education must be matured again. The link and match program of SMK with the industrial world needs to be more intensive to align the competencies taught to the competency needs of the industrial world, so that the absorption of graduates can be improved.

This is an open access article under the $\underline{C C B Y-S A}$ license.

Copyright (C) 2021 by Author. Published by Universitas Pendidikan Ganesha.

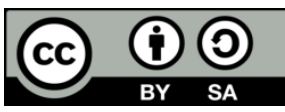

\section{INTRODUCTION}

Vocational education is education that has the aim of producing graduates who are ready to work in certain relevant areas of expertise (Billett, 2011; Miller, 2020; Sudira, 2017). Vocational education focuses on the industrial world which is the main target in facilitating graduates to have careers in the world of work (Kuswana, 2019; Sauli, 2021). Various revitalization efforts have been carried out, starting with improving proper facilities and infrastructure, fulfilling the standards of educators, to developing learning models and media (Ifeoma Obidile, 2018; Mutohhari, Sudira, et al., 2021; Nurtanto, Arifin, et al., 2020; Snell, 2019). In addition, building partnerships between vocational education and industry has been intensified to encourage collaboration and adjustment of learning needs with existing competency needs in the industry (Klatt et al., 2018; Kuswana, 2019). The main objective of these efforts is to fulfill the aspect of absorption of high vocational education graduates in the industrial world (Lindvig \& Mathiasen, 2020; Sariwulan et al., 2020).

As one of the institutions for developing human resources, vocational education, one of which is a vocational high school (SMK) is required to fulfill the aspect of high absorption of graduates in the industrial world (Akhter et al., 2021; Gishti, 2018; Nurtanto et al., 2021). The absorption of graduates in the industrial world is one of the indicators of the success of vocational education (Nießen et al., 2020; Sudira, 2017). However, the relevance of the industrial world which is the absorption of graduates must also be adjusted. The 
relevance of the work carried out by vocational high school graduates is a crucial issue today. Previous research revealed that $65 \%$ of vocational education graduates are not absorbed (Hidayatuloh \& Muslim, 2021; Sariwulan et al., 2020). The crucial problem for vocational high school graduates is currently shown by data from the Central Statistics Agency (BPS). The absorption of vocational graduates in industry tends to show the lowest level compared to other education. BPS data released in August 2020 shows the percentage of the open unemployment rate (TPT) for SMK is $8.49 \%$ (Statistik, 2020). The open unemployment data at the SMK occupies the highest rank of other types of education. Based on the results of this BPS survey, it shows that the uptake of SMK graduates currently has serious problems and requires the right solution.

Automotive is one of the areas of expertise in vocational high schools in Indonesia. Engineering, repair, maintenance, and business techniques are taught through these areas of expertise (Espinosa et al., 2021; Theissler et al., 2021). The automotive sector consists of several expertise programs, namely light vehicle engineering (TKR), motorcycle engineering and business (TBSM), heavy equipment engineering (TAB), automotive body engineering (TBO), automotive engineering (TO), automotive maintenance management techniques (TMPO), and automotive power and energy conversion (OD \& KE). The focus of this research is on light vehicle engineering and motorcycle engineering and business skills programs. These two skill programs are the skill programs that are most in demand by students (Balan et al., 2019; Theissler et al., 2021; Yu \& Wang, 2019). Based on the results of researchers' observations carried out in the province of Yogyakarta, there are $78.22 \%$ of SMKs holding light vehicle engineering expertise programs. Meanwhile, the motorcycle business and engineering expertise program shows a percentage of $82.64 \%$. This is certainly an indicator that the two skill programs are expertise programs that occupy the highest rank based on the number of applicants.

The high number of enthusiasts in light vehicle engineering and motorcycle business engineering programs should be given special attention by vocational education. Vocational education through stakeholders in it must pay attention to the efficiency of graduates in entering jobs in the relevant industrial world (S. Choi, 2021; Miller, 2020; Oswald-Egg \& Renold, 2021; Sariwulan et al., 2020). The high number of applicants must be adjusted to the availability of relevant jobs that can accommodate the output of the vocational high school in the expertise program. Competence development in accordance with the needs of the industrial world today must be carried out (Mukhadis et al., 2019). In addition, the collaboration between the two expertise programs and the automotive industry must also be more intensive (Handayani et al., 2019). The implementation of industry-based learning and the provision of tools that exist in the industry are very important, so that the competence of graduates can meet the relevant industry qualifications to be entered (Afandi \& Sentot Wijanarka, 2019).

Based on the description above, this study will analyze the extent to which graduates from the automotive sector are absorbed, which consists of two vocational skills programs, namely light vehicle engineering and motorcycle engineering and business. There are three research questions, namely as follows: (1) How is the absorption of light vehicle engineering graduates in the industrial world? (2) How is the absorption of graduates of motorcycle engineering and business skills programs in the industrial world? (3) How is the absorption ratio between graduates of the light vehicle engineering study program and graduates of motorcycle engineering and business?

\section{METHOD}

This research is a descriptive-research with a quantitative approach to measure the level of absorption of automotive graduates in the industrial world. This research was conducted in four vocational high schools (SMK) in Sleman Regency, namely SMK N 1 Seyegan, SMK N 2 Depok, SMK Diponegoro Depok, and SMK S Muhammadiyah Moyudan. The light vehicle engineering (TKR) and motorcycle engineering and business (TBSM) expertise programs in the four vocational schools were involved in this research.

The subjects in the study were data on the absorption of graduates from four Special Employment Exchanges (BKK) in the last two years (2019 \& 2020) from light vehicle engineering study programs and motorcycle engineering and business in 4 vocational schools. The number of graduate data obtained in the last two years is 467 graduates. The graduate data obtained are shown in Table 1.

Table 1. Number of Graduate Samples

\begin{tabular}{lccc}
\hline \multicolumn{1}{c}{ Name of Schools } & \multirow{2}{*}{ Status } & \multicolumn{2}{c}{ Number of Graduate Samples } \\
\cline { 3 - 4 } & & N TKR (\%) & N TBSM (\%) \\
\hline SMK N 1 Seyegan & Public school & $62(2.68)$ & $75(30.36)$ \\
SMK N 2 Depok & Public school & $68(30.36)$ & $70(28.81)$ \\
SMK S Diponegoro Depok & Private school & $42(18.75)$ & $45(18.52)$ \\
SMK S Muhammadiyah Moyudan & Private school & $52(23.21)$ & $53(21.81)$ \\
\hline
\end{tabular}




\begin{tabular}{llcc}
\hline \multirow{2}{*}{ Name of Schools } & \multirow{2}{*}{ Status } & \multicolumn{2}{c}{ Number of Graduate Samples } \\
\cline { 3 - 4 } Total & & N TKR (\%) & N TBSM (\%) \\
\hline
\end{tabular}

The data collection techniques were carried out using the observation method. Observations were made on four special job fairs (BKK) in four vocational schools. The research instrument used a graduate absorption observation sheet. The variables used in compiling the observation instrument are shown in Table 2.

Table 2. Observation Variable

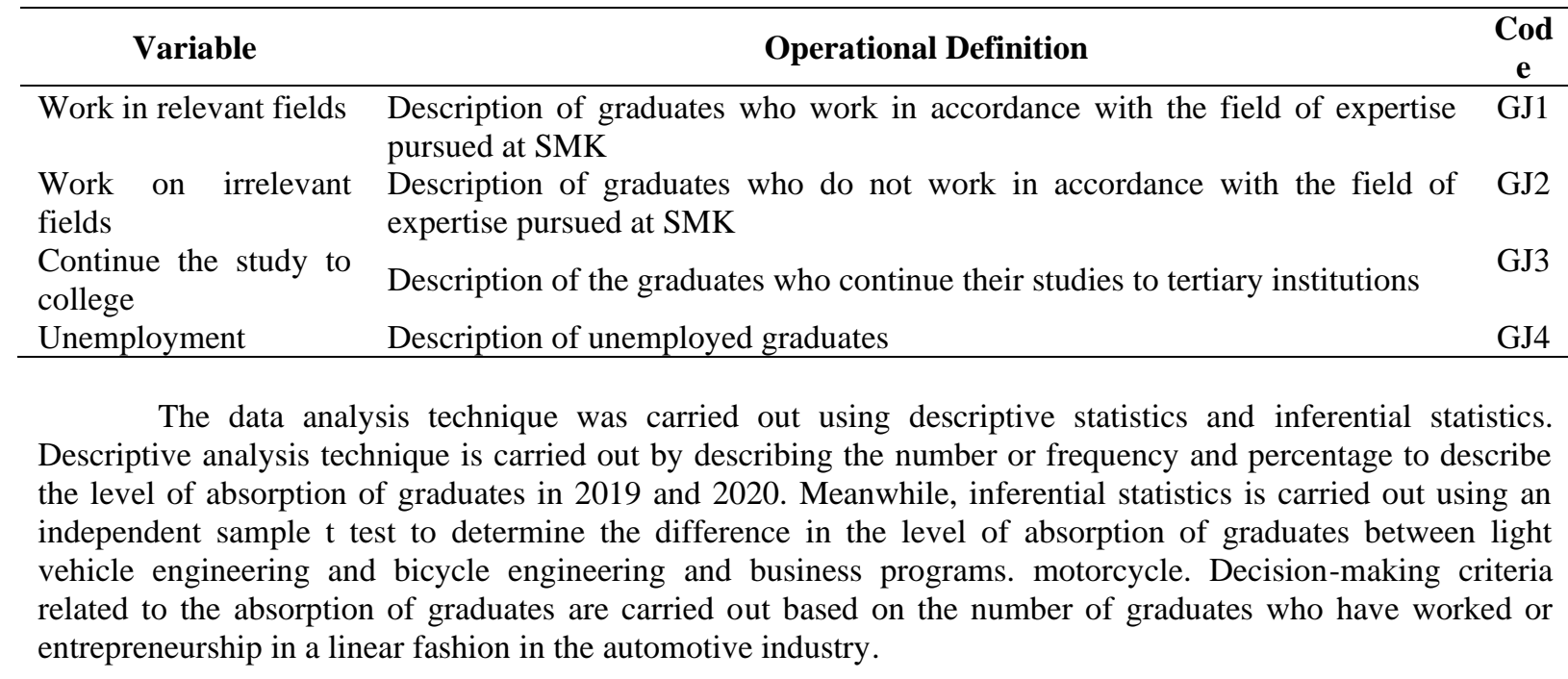

\section{RESULT AND DISCUSSION}

\section{Result}

The results of the study were obtained through secondary data, namely the results of a survey conducted by the Special Job Exchange from SMK N 1 Seyegan, SMK N 2 Depok, SMK Diponegoro Depok, and SMK S Muhammadiyah Moyudan on the light vehicle engineering program (TKR) and bicycle engineering and business. motors (TBSM). Data on the number of graduates obtained in this study were 467 graduates. The results of the analysis are displayed in the form of descriptive statistics and inferential statistics using the test. The results of data analysis on the absorption of vocational high school graduates from light vehicle engineering and motorcycle engineering and business programs in 2019 were obtained from secondary data from the BKK survey of 224 graduates. The number of graduates is divided into 2, namely 128 graduates of the light vehicle engineering program and 96 graduates of the motorcycle engineering and business expertise program. Based on the results of the data analysis above, it is known that $40.63 \%$ of SMK graduates of the light vehicle engineering program in 2019 were absorbed in the automotive industry. The percentage of absorption is in the low category. The percentage of absorption is divided into 3 parts, namely $11.72 \%$ of graduates work in official workshops, $19.53 \%$ of graduates work in general workshops, and $9.38 \%$ of graduates are entrepreneurs in the automotive sector. Meanwhile, $36.72 \%$ of graduates are not absorbed in the relevant industry. The percentage of nonabsorption of graduates is in the low category. The percentage of unabsorbed graduates is divided into 2 parts, namely $25 \%$ working outside the automotive sector, $11.72 \%$ entrepreneurship outside the automotive sector. Then students who continue their studies to college are $14.2 \%$ and the remaining $8.63 \%$ are still unemployed.

Meanwhile, the results of data analysis on the absorption of 2019 graduates in the motorcycle engineering and business expertise program. Based on the results of the analysis of the data above, it is known that $38.54 \%$ of SMK graduates of the motorcycle engineering and business expertise program in 2019 were absorbed in the automotive industry. The percentage of absorption is in the low category. The percentage of absorption is divided into 3 parts, namely $17.71 \%$ of graduates work in official workshops, $12.50 \%$ of graduates work in general workshops, and $12.50 \%$ of graduates are entrepreneurs in the automotive sector. Meanwhile, $40.63 \%$ of graduates are not absorbed in the relevant industry. The percentage of unabsorbed graduates is in the low category. The percentage of non-absorption of graduates is divided into 2 parts, namely $28.13 \%$ working outside the automotive sector, and $12.50 \%$ entrepreneurship outside the automotive sector. Then $11.46 \%$ continue their studies to college, and $9.37 \%$ are still unemployed.

After knowing the description of the absorption of graduates between the light vehicle engineering and motorcycle engineering and business skills program, then an analysis was carried out using inferential statistics 
with an independent sample $t$ test to determine whether there was a significant difference in the absorption between the two skill programs or not. Sample independent t-test was performed using SPSS V21. The results of the independent sample t-test obtained a t-count value of 1.7884 with a significance value of 0.82 . The $t$-count value is $1.7884<1.97190$ and the sig value is $0.82>0.050$. Thus, it can be interpreted that there is no significant difference between the absorption of light vehicle engineering graduates and motorcycle engineering and business graduates in 2019. In other words, the absorption of light vehicle engineering graduates as well as motorcycle engineering and business has the same category, which is low. The difference in absorption between graduates of the light vehicle engineering program and motorcycle engineering and business is shown in graph 1 below.

The results of the comparative analysis show that the absorption of light vehicle engineering graduates is higher than the absorption of graduates of motorcycle engineering and business skills programs. This is also directly proportional to the non-absorption of scrubs in the automotive industry. Motorcycle engineering and business have a higher percentage of non-absorption than light vehicle engineering. The results of data analysis on the absorption of vocational high school graduates from light vehicle engineering and motorcycle engineering and business programs in 2020 were obtained from secondary data from the BKK survey of 243 graduates. The number of graduates is divided into 2, namely 125 graduates of the light vehicle engineering program and 117 graduates of the motorcycle engineering and business expertise program. Based on the results of the data analysis above, it is known that $34.40 \%$ of SMK graduates of the light vehicle engineering program in 2020 are absorbed in the automotive industry. The percentage of absorption of these graduates is in the low category. The percentage of absorption is divided into 3 parts, namely $9.60 \%$ of graduates work in official workshops, $17.60 \%$ of graduates work in general workshops, and $7.20 \%$ of graduates are entrepreneurs in the automotive sector. Meanwhile, $42.80 \%$ of graduates are not absorbed in the relevant industry. The percentage of non-absorption of graduates is in the low category. The percentage of unabsorbed graduates is divided into 2 parts, namely $32.80 \%$ working outside the automotive sector, $9.60 \%$ entrepreneurship outside the automotive sector. Then $11.20 \%$ continue their studies to college, and $12.00 \%$ are still unemployed.

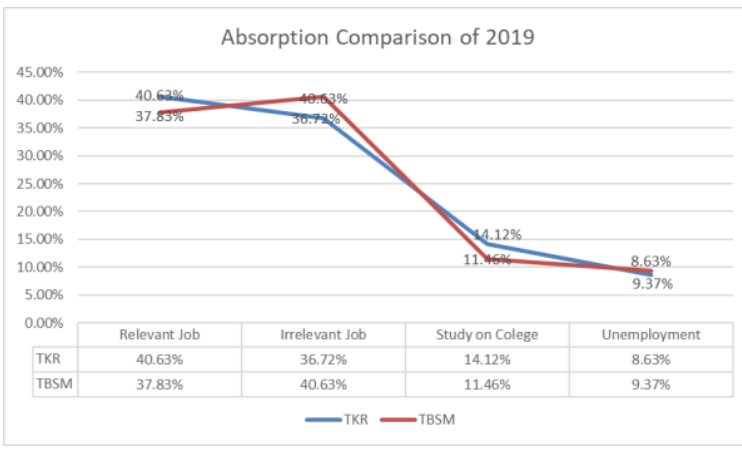

Figure 1. Comparison of Absorption Rates Between TKR and TBSM in 2019

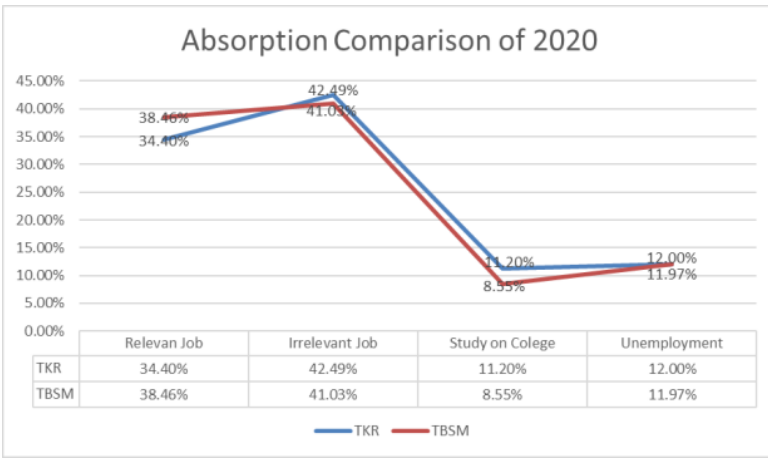

Figure 2. Comparison of Absorption Rates Between TKR and TBSM in 2020

Meanwhile, the results of data analysis on the absorption of 2019 graduates in the motorcycle engineering and business expertise program. Based on the results of the analysis of the data above, it is known that $38.46 \%$ of SMK graduates of the motorcycle engineering and business skills program in 2020 are absorbed in the automotive industry. The percentage of absorption is in the low category. The percentage of absorption is divided into 3 parts, namely $12.82 \%$ of graduates work in official workshops, $16.24 \%$ of graduates work in general workshops, and $9.40 \%$ of graduates are entrepreneurs in the automotive sector. Meanwhile, $41.03 \%$ of graduates are not absorbed in the relevant industry. The percentage of unabsorbed graduates is in the high category. The percentage of unabsorbed graduates is divided into 2 parts, namely $30.77 \%$ working outside the automotive sector, $10.26 \%$ entrepreneurship outside the automotive sector. Then students who continue their studies to college are $8.55 \%$, and $11.97 \%$ are still unemployed. After knowing the description of the absorption of graduates between the light vehicle engineering and motorcycle engineering and business skills program, then an analysis was carried out using inferential statistics with an independent sample t test to determine whether there was a significant difference in the absorption between the two skill programs or not. Sample independent $t-$ test was performed using SPSS V21. The results of the independent sample t-test obtained a t-count value of 1.728 with a significance value of 0.064 . The t-count value is $1.728<1.86190$ and the sig value is $0.064>0.050$. Thus, it can be interpreted that there is no significant difference between the absorption of light vehicle engineering and motorcycle engineering and motorcycle engineering graduates in 2020 . The difference in 
absorption between light vehicle engineering and motorcycle engineering and business engineering graduates is shown in graph 2 below. The irrelevance of jobs owned by graduates majoring in light vehicle engineering at vocational high schools in 2020 occupies the highest percentage of other aspects. Meanwhile, students who are still unemployed are the lowest in that department. Then for the motorcycle engineering and business majors, it places the irrelevant aspects of the jobs owned by graduates at a high percentage as well. Meanwhile, further study to university is the lowest.

\section{Discussion}

The results of research on the absorption of graduates of the light vehicle engineering program and motorcycle engineering and business in the relevant industrial world in 2019 and 2020 show a low percentage. The low absorption of graduates is indicated by the dominance of graduates' work which is contrary to their field of expertise when studying at SMK. In addition, unemployment is also an indicator that contributes to low absorption in the light vehicle engineering department as well as motorcycle engineering and business. The results of this study are supported by previous studies that analyzed the absorption of school graduates based on their performance. The research reveals the fact that graduates of vocational education have a low level of graduate absorption compared to other types of education (Abbas \& Sagsan, 2020; S. Choi, 2021). Other studies also reveal that the absorption of vocational education is lower due to the complexity of the competencies that must be mastered by graduates (Berge, 2018; Prosekov et al., 2020). This certainly reinforces that the problem has happened before and has been going on for a long time.

The non-absorption of labor or graduates is influenced by several factors. The competence of the workforce is the main factor that affects its absorption in the industrial world (Korkmaz \& Karakus, 2019; Li \& Miller, 2013). The competencies possessed by graduates have a significant effect on the ability to enter jobs in the relevant industrial world, especially work attitude competencies (Allan, 2014; Alwahaishi, 2020). Aspects of work attitude include character, personality, work culture and work discipline (Ahad et al., 2021). The poor working attitude of students will have an impact on the smooth working process in the industrial world, so that the industrial world will provide high qualifications related to this aspect (Ma et al., 2020; Oupen et al., 2020). The poor work attitude of graduates is also exacerbated by the low work competence related to hard skills (Suyanto, 2018). This becomes the complexity of the problems that occur in graduates and becomes a dominant factor in influencing absorption (Yuliandi \& Tahir, 2019). The competence of the workforce that is not in accordance with the qualifications of the industrial world will make it difficult for workers to enter the industrial world, so the goal is to increase the number of non-absorption of workers in the relevant industrial world. (S. J. Choi et al., 2019). In addition, the thorough preparation carried out by vocational high schools is also a crucial factor in shaping the work readiness of graduates, thus affecting the linearity of their work (Pratama et al., 2019; Sudana et al., 2019).

Another problem that becomes a crucial factor is the motivation, interest, and job satisfaction offered by the industrial world (Herman \& Didin, 2020). These aspects are very important to fulfill, so that interest in working in relevant industries will emerge from the graduates, which in turn will increase the number of graduates' absorption (Ollikainen \& Karhunen, 2021; Stellmacher et al., 2020). In addition, the work environment must also ensure comfort and safety at work, so that it will give motivation and interest to work as well as prospective workers (Bui \& Do Van Dung, 2019; Indrayanto et al., 2018). Technological developments in the 21 st century and the era of digital transformation also affect the absorption of SMK graduates (Chalkiadaki, 2018; Devi et al., 2020). The maturity level of graduates towards mastering digital technology is very important to have. The results of the study which show that the absorption rate of vocational education graduates is still low, especially in the automotive sector is very relevant. Previous research revealed that vocational teachers still have a low level of maturity in using digital technology in learning (Astuti et al., 2021; Mutohhari, Sofyan, et al., 2021). Thus, competencies based on the 21 st century and industry 4.0 are difficult to build, so the estuary of current graduate absorption tends to be low.

The complexity of the problems faced by vocational education is very important to be resolved immediately (Kratz et al., 2019). Various efforts must be made to improve students' attitudes and work competencies. Vocational education needs to encourage students' self-development and strengthen good work attitudes and in accordance with industrial work culture (Indiyaningsih et al., 2020; Tentama \& Riskiyana, 2020). Vocational education is also very important in developing teacher work competencies through training and apprenticeships, so that industrial competencies possessed by teachers can be channeled to students (Lindvig \& Mathiasen, 2020; Stellmacher et al., 2020). In addition, efforts to respond to technological developments that exist in the 21 st century and industry 4.0 must also be carried out, so that the absorption of graduates can be increased (Wagiran et al., 2019). Various competency developments based on 21st century skills and industry 4.0 are needed to meet current competency needs, so as to increase the absorption of vocational education (Bui \& Do Van Dung, 2019; Nurtanto, Sofyan, et al., 2020). 
This study has limitations that cannot be carried out by researchers, namely related to the research sample which is only limited to two majors. In addition, this study also has limitations related to revealing in depth the factors that can affect the low absorption of vocational education graduates in Indonesia specifically in the light vehicle engineering department, and motorcycle engineering and business. Thus, the researcher really hopes that the next research will reveal the absorption of graduates in the future and analyze in depth the factors that affect the absorption of vocational education graduates, especially in Indonesia.

\section{CONCLUSION}

The light vehicle engineering expertise program (TKR), and motorcycle engineering and business (TBSM) are two of the many skill programs in vocational education with the problem of absorption of graduates. In the last two years, the absorption in the two majors is still in the low category. Meanwhile, although the number in the non-absorption aspect of graduates is also low, it is still the highest contributor among other aspects. Both the light vehicle engineering expertise program as well as motorcycle engineering and business have the same level of absorption of graduates. Various efforts to revitalize vocational education must be matured again. Strengthening work attitudes, maturation of work competencies, and retraining for teachers are feasible solutions to increase the absorption rate of graduates. This study has limitations that are only carried out in two majors and have not revealed the deep factors that can affect the low absorption of vocational education graduates in Indonesia, especially in the light vehicle engineering department, as well as motorcycle engineering and business. Researchers really hope that further research can reveal the absorption of graduates in the future and analyze in depth the factors that affect the absorption of graduates.

\section{REFERENCES}

Abbas, J., \& Sagsan, M. (2020). Identification of key employability attributes and evaluation of university graduates' performance: Instrument development and validation. Higher Education, Skills and WorkBased Learning, 10(3), 449-466. https://doi.org/10.1108/HESWBL-06-2019-0075.

Afandi, K., \& Sentot Wijanarka, B. (2019). Outcomes of Vocational High Schools in Machining Expertise in the Labor Market in Yogyakarta, Indonesia. American Journal of Educational Research, 7(9), 599-603. https://doi.org/10.12691/education-7-9-1.

Ahad, R., Mustafa, M. Z., Mohamad, S., Abdullah, N. H. S., \& Nordin, M. N. (2021). Work attitude, organizational commitment and emotional intelligence of Malaysian vocational college teachers. Journal of Technical Education and Training, 13(1), 15-21. https://doi.org/10.30880/jtet.2021.13.01.002.

Akhter, Z., Malik, G., \& Plummer, V. (2021). Nurse educator knowledge, attitude and skills towards using highfidelity simulation: A study in the vocational education sector. Nurse Education in Practice, 53. https://doi.org/10.1016/j.nepr.2021.103048.

Allan, D. (2014). Dealing with disaffection: the influence of work-based learning on 14-16-year-old students' attitudes to school. Empirical Research in Vocational Education and Training, 6(1), 1-18. https://doi.org/10.1186/s40461-014-0010-4.

Alwahaishi, S. (2020). Influence of Work-based Learning on Students' Ethical Orientation. 2020 International Conference on Innovation and Intelligence for Informatics, Computing and Technologies, 3ICT 2020, 1-12. https://doi.org/10.1109/3ICT51146.2020.9311980.

Astuti, M., Arifin, Z., Mutohhari, F., \& Nurtanto, M. (2021). Competency of Digital Technology: The Maturity Levels of Teachers and Students in Vocational Education in Indonesia. Journal of Education Technology, 5(2), 254-262. https://doi.org/10.23887/jet.v5i3.35108.

Balan, L., Yuen, T., \& Mehrtash, M. (2019). Problem-Based Learning Strategy for CAD Software Using FreeChoice and Open-Ended Group Projects. Procedia Manufacturing, 32, 339-347. https://doi.org/10.1016/j.promfg.2019.02.223.

Berge, W. van den. (2018). Bad start, bad match? The early career effects of graduating in a recession for vocational and academic graduates. Labour 23. https://doi.org/10.1016/j.labeco.2018.05.011.

Billett, S. (2011). Vocational Education: Purposes, Traditions and Prospects. Springer. https://doi.org/10.1007/978-94-007-1954-5.

Bui, V. H., \& Do Van Dung. (2019). Development of Vietnamese Vocational Education Teachers to adapt the Industrial Revolution 4.0. Asian Journal of Interdisciplinary Research, 2(4), 1-7. https://doi.org/10.34256/ajir1941.

Chalkiadaki, A. (2018). A systematic literature review of 21 st century skills and competencies in primary 
education. International Journal of Instruction, 11(3), 1-16. https://doi.org/10.12973/iji.2018.1131a.

Choi, S. (2021). The impact of education levels and paths on labor market outcomes in South Korea: Focusing on vocational high school graduates. Social Sciences \& Humanities Open, 4(1). https://doi.org/10.1016/j.ssaho.2021.100152.

Choi, S. J., Jeong, J. C., \& Kim, S. N. (2019). Impact of vocational education and training on adult skills and employment: An applied multilevel analysis. International Journal of Educational Development, 66(12), 129-138. https://doi.org/10.1016/j.ijedudev.2018.09.007.

Devi, M., Annamalai, M. A. R., \& Veeramuthu, S. P. (2020). Literature education and industrial revolution 4.0. Universal Journal of Educational Research, 8(3), 1027-1036. https://doi.org/10.13189/ujer.2020.080337.

Espinosa, R., Ponce, H., \& Gutiérrez, S. (2021). Click-event sound detection in automotive industry using machine/deep learning. Applied Soft Computing, 108. https://doi.org/10.1016/j.asoc.2021.107465.

Gishti, E. (Shehi). (2018). Social Partnership in Vocational Education and Training in Albania. European Journal of Education, 1(3), 163-169. https://doi.org/10.26417/ejed.v1i3.p163-169.

Handayani, S., Raharjo, T. J., \& ... (2019). Management Strategy of SMK Negeri 3 Semarang in An Effort to Increase the Absorption Capacity of Graduates through Cooperatives in the Business and Industrial .... Educational Management, 8(7), 157-164.

Herman, \& Didin, D. (2020). The influence of work motivation, job satisfaction and work discipline on employee performance in the regional secretariat of Maros district. Jurnal Ad'ministrare, 7(1), 1-8. https://doi.org/10.26858/ja.v7i1.14777.

Hidayatuloh, M. K. Y., \& Muslim, S. (2021). Absorption level vocational high school graduates in industrial. Journal of Physics: Conference Series, 1833(1), 1-9. https://doi.org/10.1088/17426596/1833/1/012019.

Ifeoma Obidile, J. (2018). Revitalization of the Technical and Vocational Education (TVE) Programmes for Youth Empowerment in Nigeria. International Journal of Vocational Education and Training Research, 4(1), 45-47. https://doi.org/10.11648/j.ijvetr.20180401.17.

Indiyaningsih, K. M. H., Murdyastuti, A., \& Puspitaningtyas, Z. (2020). Efeect of human resource competency, work culture and utilization of information technology to performance of employees. International Journal of Scientific and Technology Research, 9(4), 3636-3641. https://doi.org/10.19184/issrd.v2i1.17468.

Indrayanto, A., Nugroho, S. W. ., Nurfitri, T., \& Hongbo, D. (2018). Influence of Work Motivation and Work Environment on Competitive Advantage. Journal of Applied Management (JAM), 16(1), 1-8. https://jurnaljam.ub.ac.id/index.php/jam/article/view/1219/965.

Klatt, G., Angelico, T., \& Polesel, J. (2018). Emerging partnership practices in VET provision in the senior years of schooling in Australia. Australian Educational Researcher, 45(2), 217-236. https://doi.org/10.1007/s13384-017-0244-9.

Korkmaz, O., \& Karakus, U. (2019). The Impact of Blended Learning Model on Student Attitudes Towards Geography Course and Their Critical Thinking Dispositions and Levels. The Turkish Online Journal of Educational Technology, 8(4). https://eric.ed.gov/?id=EJ859497.

Kratz, F., Patzina, A., Kleinert, C., \& Dietrich, H. (2019). Vocational education and employment: Explaining cohort variations in life course patterns. Social Inclusion, 7(3), 224-253. https://doi.org/10.17645/si.v7i3.2045.

Kuswana, H. (2019). The Effect Of Managerial Capabilities Of Principal Toward School Quality In Vocational High School. Jurnal Kepemimpinan Pendidikan, 2(1). https://doi.org/10.22236/jkpuhamka.v2i1.3805.

Li, I. W., \& Miller, P. W. (2013). The Absorption of Recent Graduates into the Australian Labour Market: Variations by University Attended and Field of Study. Australian Economic Review, 46(1), 14-30. https://doi.org/10.1111/j.1467-8462.2013.00713.x.

Lindvig, K., \& Mathiasen, H. (2020). Translating the Learning Factory model to a Danish Vocational Education Setting. Translating the Learning Factory Model to a Danish Vocational Education Setting, 45. https://doi.org/10.1016/j.promfg.2020.04.077.

Ma, H. Y., Kao, J. C., Kao, R. H., \& Cho, C. C. (2020). How to shape the employees' sustainable work attitude: The moderating effect of supervisor attitudes. Sustainability (Switzerland), 12(20), 1-27. https://doi.org/10.3390/su12208331.

Miller, A. (2020). Development through vocational education. The lived experiences of young people at a vocational education, training restaurant in Siem Reap, Cambodia. Heliyon, 6(12). https://doi.org/10.1016/j.heliyon.2020.e05765.

Mukhadis, A., Putra, A. B. N. R., Irdianto, W., Ismail, A., \& Achmad, F. (2019). Analysis of Self Concept and Graduation Capability in the Era of Industrial Revolution 4.0 to Increase Absorption of Vocational Student Graduates. 283-292. https://doi.org/10.2991/assehr.k.191217.046. 
Mutohhari, F., Sofyan, H., \& Nurtanto, M. (2021). Technological Competencies: A Study on the Acceptance of Digital Technology on Vocational Teachers in Indonesia. Proceedings of the 1st International Conference on Law, Social Science, Economics, and Education, ICLSSEE 2021, 1-11. https://doi.org/10.4108/eai.6-3-2021.2305971.

Mutohhari, F., Sudira, P., \& Nurtanto, M. (2021). Automotive Engineering Drawing Learning: Effective Online Learning Using Autocad Application. Journal of Education Technology, 5(2), 214-219. https://doi.org/10.23887/jet.v5i2.33197.

Nießen, D., Danner, D., Spengler, M., \& Lechner, C. M. (2020). Big Five Personality Traits Predict Successful Transitions From School to Vocational Education and Training: A Large-Scale Study. Frontiers in Psychology, 11(4), 1-18. https://doi.org/10.3389/fpsyg.2020.01827.

Nurtanto, M., Arifin, Z., Sofyan, H., Warju, W., \& Nurhaji, S. (2020). Development of model for professional competency assessment (Pca) in vocational education: Study of the engine tune-up injection system assessment scheme. Journal of Technical Education and Training, 12(2), 34-45. https://doi.org/10.30880/jtet.2020.12.02.004.

Nurtanto, M., Kholifah, N., Masek, A., Sudira, P., \& Samsudin, A. (2021). Crucial problems in arranged the lesson plan of vocational teacher. International Journal of Evaluation and Research in Education (IJERE), 10(1), 345-354. https://doi.org/10.11591/ijere.v10i1.20604.

Nurtanto, M., Sofyan, H., Pardjono, P., \& Suyitno, S. (2020). Development model for competency improvement and national vocational qualification support frames in automotive technology. International Journal of Evaluation and Research in Education, 9(1), 168-176. https://doi.org/10.11591/ijere.v9i1.20447.

Ollikainen, J.-P., \& Karhunen, H. (2021). A tale of two trade-offs: Effects of opening pathways from vocational to higher education. Economics Letters, 205. https://doi.org/10.1016/j.econlet.2021.109945.

Oswald-Egg, M. E., \& Renold, U. (2021). No experience, no employment: The effect of vocational education and training work experience on labour market outcomes after higher education. Economics of Education Review, 60. https://doi.org/10.1016/j.econedurev.2020.102065.

Oupen, S. M., Agung, A. A. G., \& Yudana, I. M. (2020). Kontribusi Kepemimpinan Transformasional, Budaya Organisasi, Disiplin Kerja dan Motivasi Kerja Terhadap Komitmen Organisasional Guru SD. Jurnal Administrasi Pendidikan Indonesia, 11(1), 32-41. https://doi.org/10.23887/japi.v11i1.3167.

Pratama, S. A., Winanti, E. T., \& Wardhono, A. (2019). Profile of 3 years and 4 years vocational school Relationship with the preparation of graduates Building engineering expertise program. International Journal for Educational and Vocational Studies, 1(6), 623-626. https://doi.org/10.29103/ijevs.v1i6.1787.

Prosekov, A. Y., Morozova, I. S., \& Filatova, E. V. (2020). A case study of graduate quality: Subjective opinions of participants in the sphere of education. European Journal of Contemporary Education, 9(1), 114 125. https://doi.org/10.13187/ejced.2020.1.114.

Sariwulan, T., Widodo, Perdana, N. S., Fajarini, \& Agung, I. (2020). The influence of absorption graduates vocational education: A case study. Academic Journal of Interdisciplinary Studies, 9(2), 55-71. https://doi.org/10.36941/ajis-2020-0023.

Sauli, F. (2021). The collaboration between Swiss initial vocational education and training partners: perceptions of apprentices, teachers, and in-company trainers. Empirical Research in Vocational Education and Training, 13(1), 1-14. https://doi.org/10.1186/s40461-021-00114-2.

Snell, D. (2019). Vocational education and the revitalisation of manufacturing in the United States. Journal of Vocational Education and Training, 71(2), 239-259. https://doi.org/10.1080/13636820.2018.1480520.

Statistik, B. P. (2020). Data Sensus : Tingkat Pengangguran Terbuka Berdasarkan Pendidikan Tertinggi yang Ditamatkan.

Stellmacher, A., Ohlemann, S., Pfetsch, J., \& Ittel, A. (2020). Pre-service teacher career choice motivation: A comparison of vocational education and training teachers and comprehensive school teachers in Germany. International Journal for Research in Vocational Education and Training, 7(2), 214-236. https://doi.org/10.13152/IJRVET.7.2.5.

Sudana, I., Apriyani, D., \& Nurmasitah, S. (2019). Revitalization of vocational high school roadmap to encounter the 4.0 industrial revolution. Journal of Social Sciences Research, 5(2), 338-342. https://doi.org/10.32861/jssr.52.338.342.

Sudira, P. (2017). Tvet Abad XXI : Filosofi, Teori, Konsep, dan Strategi Pembelajaran Vokasional. UNY Press.

Suyanto, S. (2018). Competence and discipline on work motivation and the implication on working performance. European Research Studies Journal, 21(1), 570-587. https://doi.org/10.35808/ersj/971.

Tentama, F., \& Riskiyana, E. R. (2020). The role of social support and self-regulation on work readiness among students in vocational high school. International Journal of Evaluation and Research in Education, 9(4), 826-832. https://doi.org/10.11591/ijere.v9i4.20578.

Theissler, A., Pérez-Velázquez, J., Kettelgerdes, M., \& Elger, G. (2021). Predictive maintenance enabled by 
machine learning: Use cases and challenges in the automotive industry. Reliability Engineering \& System Safety, 215. https://doi.org/10.1016/j.ress.2021.107864.

Wagiran, Pardjono, Suyanto, W., Sofyan, H., Soenarto, S., \& Yudantoko, A. (2019). Competencies of Future Vocational Teachers: Perspective of in-Service Teachers and Educational Experts. Cakrawala Pendidikan, 38(2), 388-400. https://doi.org/10.21831/cp.v38i2.25393.

Yu, W., \& Wang, R. (2019). Development and performance evaluation of a comprehensive automotive energy recovery system with a refined energy management strategy. Energy, 189. https://doi.org/10.1016/j.energy.2019.116365.

Yuliandi, \& Tahir, R. (2019). Work discipline, competence, empowerment, job satisfaction, and employee performance. International Journal of Recent Technology and Engineering, 8(3), 7209-7215. https://doi.org/10.35940/ijrte.C6221.098319. 